\title{
Contract Functions in Service Exchange Governance: Evidence from Logistics Outsourcing
}

To Appear in the Production Planning \& Control

[In Press]

\section{Kostas Selviaridis*}

Assistant Professor of Operations Management

Department of Management Science

Lancaster University Management School

LA1 4YX, Lancaster, United Kingdom

Email: k.selviaridis@lancaster.ac.uk

Tel: $+44(0) 1524594602$

* Corresponding author. Email: k.selviaridis@lancaster.ac.uk 


\title{
Contract Functions in Service Exchange Governance: Evidence from Logistics Outsourcing
}

\begin{abstract}
The logistics outsourcing literature emphasises relational governance mechanisms and has underplayed the role of formal contractual provisions. This paper empirically examines the multiple functions that contracts perform in service exchange governance. Codification, safeguarding, coordination, and adaptation functions are linked to contract specification schedules, payment mechanisms, (early) termination rights, performance review and communication provisions, service variations clauses, and renegotiation provisions. Contracts may also embody exchange- or partner-specific learning, albeit to a limited extent. Overall, the empirical findings lend support to the functional view of contracting. The functionality of contracts extends beyond safeguarding against opportunism and financial losses. In addition to offering economic and legal safeguards, contracts are used to coordinate and adapt service exchanges in the face of complexity and uncertainty.
\end{abstract}

Keywords: contracting; exchange governance; contract functions; business services; logistics outsourcing 


\section{Introduction}

The aim of this paper is to empirically examine how contracts govern service exchanges in the context of logistics outsourcing. The focus is on formal contracts with legally enforceable provisions, rather than implicit contracts and verbal agreements (Lusch and Brown 1996). The paper stresses a functional view of contracting which directs attention to the functions that contracts perform in addition to safeguarding against opportunism (Schepker et al. 2014).

Logistics outsourcing, also referred to as third party logistics (3PL), is the established practice of contracting out logistics activities or functions that were previously executed inhouse (Selviaridis and Spring 2007). Effective governance of customer-logistics service provider (LSP) exchanges is important for achieving cost reduction and improved performance benefits (Solakivi, Töyli, and Ojala 2013; Chen, Goan and Huang 2011; Jayaram and Tan 2010), and formal contracts play a key part in managing exchange relations (Cao and Lumineau 2015). Consider the example of the UK National Health Service (NHS) outsourcing the procurement, storage and distribution of hospital supplies to DHL Supply Chain Ltd. The parties have entered a ten-year contract estimated to affect medical goods and services worth of $£ 22$ billion, which is also expected to result in more than $£ 1$ billion of savings by 2016 (NHS Supply Chain 2016). Given the strategic importance and long-term horizon of this deal, it would be expected that the formal contract actively contributes to effective governance e.g. through safeguarding the investments made by the counterparts, but also through coordinating activities and facilitating adaptations to service delivery.

The existing logistics outsourcing literature, however, appears to be less concerned with the role of formal contracts in exchange governance and has mainly focused on relational mechanisms (Marasco 2008). For instance, several studies draw on a relationship marketing approach to study the impact of behavioral attributes on 3PL exchange outcomes. Trust, commitment and collaboration can, amongst other factors, enhance the outcomes of 3PL 
alliances and increase customer loyalty (Wallenburg et al. 2010; Knemeyer and Murphy 2005; Lambert, Emmelhainz, and Gardner 1999; Moore and Cunningham 1999). More recent research has focused on the role of fairness in establishing successful 3PL relationships in terms of trust building, cooperation and proactive performance improvement. Rossiter-Hofer, Knemeyer and Murphy (2012), in particular, submit that both procedural justice (i.e. perceived fairness of policy or process associated with distribution of relationship outcomes) and distributive justice (i.e. perceived fairness of outcome/reward distribution) impact positively on customer's trust, cooperation and long-term relationship orientation.

The functions of formal contracts in this context are much less examined. Existing studies describe the typical contract structure e.g. in terms of contract duration, expected behaviors, service level targets, and risk and liabilities allocation (Wilding and Juriado 2004; Logan 2000; Boyson et al. 1999). Such literature, however, offers limited insights into how specific contractual provisions may contribute to exchange governance (Hofenk et al. 2011). This is important as contracts perform multiple functions (Schepker et al. 2014) e.g. by defining exchanges, reducing uncertainty, coordinating and adjusting service delivery and incentivising innovation (Datta and Roy 2013; Caniëls, Geldeman, and Vermeulen 2012; Wagner and Sutter 2012; Lukassen and Wallenburg 2010).

The empirical literature on the role of contracts in logistics outsourcing governance is rather limited. Selviaridis and Norrman (2015) have recently examined the design and enactment of performance-oriented provisions included in logistics service contracts, and identified challenges impacting their effectiveness in terms of customer and LSP incentive alignment. Forslund (2009) suggests that contractual performance goals and indicators contribute to performance measurement and management processes, but that additional capabilities (e.g. data analysis) are needed. Halldórsson and Skjøtt-Larsen (2006) find that the formal contract cannot in itself deal with uncertainty associated with changing volumes and 
prices, and thus relational mechanisms are also deployed to adapt the service exchange. Selviaridis and Spring (2010) argue that the contract provides a basis for ongoing dialogue and exchange adaptation in cases of high uncertainty, and demonstrate the interplay of contractual and relational governance mechanisms. Similarly, Hofenk et al. (2011) conclude that formal contracts, trust and commitment are complementary in achieving effectiveness in 3PL relationships. The 3PL exchange is conceived as a dynamic process where the exchange definition is subject to continuous evaluation and adjustment and is only temporarily codified through the contractual specification (Selviaridis and Spring 2010). Each exchange is also part of a broader relationship frame and hence prior interactions influence its current design (Gadde and Huthlèn 2010; Marasco 2008).

Collectively this research stream remains divided over the role of formal contracts in logistics outsourcing governance reflecting also trends in the broader governance literature (Cao and Lumineau 2015; Vandaele et al. 2007; Klein-Woolthuis, Hillebrand, and Nooteboom 2005). Detailed contracts are either perceived as signals of lack of trust (Lambert et al. 1999), or complements to trust, commitment, flexibility and relational norms to ensure exchange effectiveness (Hofenk et al. 2011; Boyson et al. 1999). Despite their contributions, the above studies do not provide in-depth empirical insights into the functions that specific contractual provisions and clauses perform. This paper addresses this gap by empirically studying the functions of 3PL contracts in service exchange governance, considering also their interplay with relational mechanisms (Rossiter-Hofer et al. 2012; Lambert et al. 1999). The following research question (RQ) is posed: How do formal contractual provisions govern service exchanges in logistics outsourcing?

The RQ is pursued through four in-depth case studies of contractual relationships in the context of the UK logistics services industry. Data collection comprised 38 semi-structured interviews with managers of LSPs and their customers and review of relevant documents, 
notably service contracts. The study draws on transaction cost economics (TCE) and contracting and relational exchange literatures to develop an analytical frame of the design and functionality of contractual provisions in service exchange governance.

The research unpacks the function of contracts in service exchange governance, an issue that has hitherto been underplayed in the logistics outsourcing literature (Marasco 2008). It empirically demonstrates how specific contractual provisions are used to codify the service exchange, to safeguard parties against perceived risks and opportunism, to coordinate their actions to improve service delivery, and to adapt the service exchange in response to environmental changes. The paper also builds upon recent efforts to examine the role of contracts in managing (service) complexity (Kreye et al. 2015; Roehrich and Lewis 2014) by suggesting that contract functionality extends beyond safeguarding. In addition to offering economic and legal safeguards, contracts are used to coordinate and adapt service exchanges in the face of service complexity and uncertainty. Managers involved in contracting for logistics services should consider the specific conditions upon which contractual provisions and their associated functions are to be stressed to improve exchange effectiveness.

The following section reviews the relevant literature, and Section 3 discusses the research methodology. Section 4 analyses the cases, while Section 5 develops propositions regarding contract functions and discusses the findings and their research implications. Section 6 draws out contributions, managerial implications and future research avenues.

\section{Exchange governance and contract functions}

TCE theory underpins much of the contracting literature and has been widely applied to explain outsourcing decisions and the governance of 3PL exchanges in particular (Selviaridis and Spring 2007). Since TCE is well-established within operations and supply management (Zheng, Roehrich, and Lewis 2008), this section focuses on the aspects most relevant to the present 
study. TCE posits that exchange attributes determine governance choices (market vs. hierarchy) with a view to minimising transaction costs and efficiently governing economic exchanges (Williamson 1991; Masten, Meehan, and Snyder 1991). The attributes originally stressed were asset specificity, uncertainty and transaction frequency (Williamson 1985). Asset specificity, referring to idiosyncratic assets that cannot be easily redeployed to other uses, creates a safeguarding problem and explains incentives for vertical integration and long-term relationship development (Rindfleisch and Heide 1997). Uncertainty arises either when it is difficult to predict and specify ex ante exchange contingencies (environmental uncertainty), or when performance cannot be verified ex post (behavioural uncertainty). Uncertainty creates an adaptation problem raising the costs of adjusting agreements (Rindfleisch and Heide 1997). Frequency refers to transaction recurrence; high frequency provides an incentive to vertically integrate (Williamson 1985).

The market-hierarchy continuum was elaborated by explicating relational governance and 'hybrids' as an alternative (to hierarchy) way of safeguarding asset-specific transactions and adapting to changing circumstances (Williamson 1991). However, TCE has been critisised for understating the role of social interactions and trust (Geyskens, Steenkamp, and Kumar 2006; Poppo and Zenger 2002). The TCE's assertion that trust is a redundant concept insofar as it does not promote calculative behavior of exchange parties (Williamson 1993) is dismissed by other scholars (Nooteboom, Berger, and Noorderhaven 1997; McNeil 1980). The notion of trust goes beyond coercive action and self-interest and results from relationship-specific norms and social bonds. Trust, in combination with coercion and incentives, reduce the perceived risk of opportunism (Nooteboom et al. 1997). Subsequent literature has supported this view and suggested that formal contracts and trust can reinforce each other and positively influence exchange performance (Caniëls et al. 2012; Lazarinni, Miller, and Zenger 2004; Cannon, Achrol and Gundlach 2000). TCE, contracting and relational exchange literatures are 
synthesised below to develop an analytical frame of the design of formal contractual provisions, and the functions they can perform in service exchange governance.

\subsection{Exchange attributes and contract design}

TCE underpins a structural approach to contracting which stresses the 'optimal' contract structure in terms of safeguarding investments and minimising opportunism (Schepker et al. 2014). TCE posits that contract design should be aligned with exchange attributes to achieve efficient governance (Argyres and Mayer 2007; Williamson 1985). However, a TCE-inspired (structural) view of contracting is incomplete since: (a) it underplays the role of partner-specific experience and knowledge and trust, which may also influence contract design (Håkansson and Snehota 2002; Argyres and Liebeskind 1999; Ring and Van de Ven 1992), and (b) it focuses on the safeguarding role of contracts and understates their other potential functions e.g. exchange coordination and adaptation (Schepker et al. 2014; Heide 1994). In line with the conceptualization of the 3PL exchange as a dynamic process (Selviaridis, Agndal, and Axelsson 2011; Halldórsson and Skjøtt-Larsen 2006), this paper adopts a broader view of contracting which considers the role of relational experience as well as the multiple functions of contracts (in addition to safeguarding). The study focuses on two exchange attributes influencing the design and functionality of contracts, namely perceived uncertainty and relational experience. These are discussed in detail below.

\subsubsection{Perceived uncertainty}

Perceived uncertainty originates in TCE and refers both to behavioural and environmental sources of uncertainty (Williamson 1985). The former is related to difficulties in evaluating performance ex post and the associated perceived risks of moral hazard and opportunistic behaviour (Rindfleisch and Heide 1997). Environmental uncertainty refers to the dynamism 
and unpredictability of the market environment within which exchanges occur. This dynamic environment makes the definition of current and future exchange requirements problematic (Rindfleisch and Heide 1997). Environmental uncertainty relates both to volume and technological uncertainty; while the former incentivises vertical integration, the latter makes market governance preferable (Geyskens et al. 2006). Within the bounds of durable inter-firm relationships, the adaptation problem can be addressed through contractual provisions emphasising flexibility, contingency planning, and frequent communications (Argyres, Bercovitz, and Mayer 2007; Poppo and Zenger 2002).

Perceived uncertainty is also closely associated with the complexity of service exchanges (Badinelli et al. 2012; Argyres and Mayer 2007). The extant literature has associated complexity with various characteristics of service exchanges and existing definitions of service complexity depend also on their purpose and focus (Kreye, Roehrich, and Lewis 2015). In their comprehensive review of service complexity, Benedetinni and Neely (2012) defined it in terms complicatedness and difficulty. The former refers to the number of service activities /components and their interactions into delivering multiple functions, while the latter to the amount of resources needed to perform sophisticated functions. However, this definition of complexity underplays the role of service-related interactions (e.g. with customers) and the dynamic nature of services (in terms of the need to adjust the service to fit changing environmental conditions) which may also introduce uncertainty (Sampson and Spring 2012; Badinelli et al. 2012).

Service complexity is particularly relevant here because the level of complexity may influence the design and functionality of formal contracts (e.g. Roehrich and Lewis 2014) and the development of (advanced) contracting and relational capabilities (Kreye et al. 2015). Service delivery including with multiple service components interacting with one another to fulfil multiple functions often presents difficulties in terms of specifying requirements ex ante. 
Such service requirements are also subject to ongoing adjustment (Selviaridis et al. 2011). This raises the level of perceived complexity and uncertainty and may result in more detailed contracts to provide safeguards against potential opportunism (Kreye et al. 2015). Extensive contracts also entail the development of contracting capabilities, which may evolve gradually as contracting parties adapt contracting terms to increase exchange effectiveness (Spring and Araujo 2014). Hartmann et al. (2014) stress the process by which buyers and suppliers in publicprivate infrastructure projects learn to contract with each other e.g. by defining service tasks and requirements and configuring incentive systems. As part of this process of contractual interactions relational capabilities (e.g. joint problem solving and trust building) are also built. The effectiveness of elaborate contracts can be questionable, and more simplified formal agreements in combination with relational capabilities may render better results in terms of exchange performance (Roehrich and Lewis 2014).

However, the extant literature stresses the role of legal and economic safeguards (safeguarding function) and provides limited evidence of contractual provisions that help manage complexity and uncertainty through coordination or adaptation of the exchange. Similarly, the literature refers to capabilities required to perform the safeguarding function of contracts, and tends to understate contract design and execution capabilities necessary to use contracts as tools for exchange coordination and adaptation (see Spring and Araujo 2014).

\subsubsection{Relational experience}

Relational experience refers to accumulated knowledge of the counterpart's business requirements, goals, intentions and expectations (Tuli, Kohli, and Bharadwaj 2007; Ulaga and Eggert 2006; Zollo, Reuer, and Singh 2002). Partner-specific learning is enabled through buyersupplier interactions and information and knowledge sharing at multiple organisational levels (Dyer and Singh 1998). Relational experience also considers the influence of prior exchange 
experiences and trust in the design and use of contractual provisions. The broader context and history of a business relationship can influence the current exchange and its formal design (Gadde and Huthlèn 2010; Argyres and Liebeskind 1999). The extent to which extensive contractual provisions are invoked depends also on the broader relationship atmosphere (Williamson 1985) and the reliance on informal mechanisms to adapt and resolve disputes regarding the distribution of outcomes/rewards (Rossiter-Hofer et al. 2012). In presence of strong relational ties, it might be counter-productive to write extensive formal contracts detailing all potential contingencies (Lusch and Brown 1996).

The existing literature suggests that partner- and exchange-specific learning can influence contractual provisions and their level of extensiveness. Mayer and Argyres (2004) show how in repeated exchange situations parties learn how to contract and collaborate with each other, and how successive contracts are modified to enhance communication and information flow, clarify responsibilities and expectations, plan for contingencies and modify service specifications. Prior exchange experience may result in more detailed task descriptions and contingency planning (Argyres et al. 2007). Reuer and Arino (2007) find that prior interactions lead to less detailed monitoring and adaptation provisions, but they do not influence enforcement provisions (e.g. arbitration). Similarly, Vanneste and Puranam (2010) suggest that repeated exchanges lead to more extensive technical provisions, but leave legal clauses unaffected. Ryall and Sampson (2009) find that inter-firm learning leads to more detailed contracts overall. However, trust development may also lead to less elaborate intellectual property rights provisions. Chen and Bharadwaj (2009) suggest that inter-firm learning leads to more extensive monitoring, dispute resolution mechanisms and contingency planning, but it does not influence property rights due to inter-firm trust effects. 


\subsection{The multiple functions of contracts}

Reflecting a functional approach to contracting (Schepker et al. 2014), this paper suggests that contracts can serve multiple functions beyond offering legal and economic safeguards.

The safeguarding function is well established and is grounded on TCE theory (Schepker et al. 2014). In response to increasing complexity and environmental uncertainty resulting from the multiple and highly interactive service components and/or long-term exchange horizons, extensive contracts with detailed clauses that safeguard asset-specific investments are developed (Roehrich and Lewis 2014). This is intended to protect parties against potential opportunism and financial and operational uncertainties (Kern and Willcocks 2000; Williamson 1985). Contracts include several provisions and clauses that serve as legal and economic safeguards, such as the assignment of property rights and decision control rights to manage externalities, or to protect parties with low negotiating power (Klein-Woolthuis et al. 2005; Adegbesan and Higgins 2011). Early termination rights allow for contract exit and help combat potential moral hazard (Argyres and Mayer 2007). Dispute resolution mechanisms serve as legal safeguards, although their implementation also depends on the negotiating approach of the parties and the emphasis put on their contractual rights and obligations (Lumineau and Malhotra 2011). The payment mechanism also serves as an economic safeguard in that it determines the allocation of financial gains and risks (Datta and Roy 2013; Wagner and Sutter 2012; Liu et al. 2009). Cost-plus contracts, for instance, reduce financial risks for suppliers in cases of high environmental uncertainty (Kalnins and Mayer 2004; Corts and Sigh 2004).

Beyond safeguarding, contracts can perform a codification function (Mayer and Argyres 2004). Contracts, and the process of contracting in itself, help in constructing and codifying a shared exchange definition and facilitate the development of mutual understanding about parties' goals, expectations, and requirements during the exchange (Lumineau, Frechet, and Puthod 2011; Blomqvist, Hurmelinna, and Seppanen 2005). Service elements (e.g. resources) 
are codified through the contract, but deviations from the contractual specification can instigate processes of adaptation ex post (Lindberg and Nordin 2008). In the context of this ongoing evaluation and adjustment process contracts serve as temporary codification devices (Selviaridis and Spring 2010).

Contracts may also serve as coordination devices by including provisions that delineate the roles and responsibilities of contracting parties, explicate processes for monitoring of performance as well as appropriate behaviors and establishing formal communication channels across organisational boundaries (Schepker et al. 2014; Reuer and Arino 2007). Ménard (2004) suggests that coordination through contracts is a common feature among joint ventures, alliances and other 'hybrid' types. Coordination is enabled by clauses that establish formal routines for information and knowledge sharing along multiple management levels, which may enhance communication flows (Argyres and Mayer 2007; Poppo and Zenger 2002). Provisions for performance reviews and ongoing monitoring of behaviors (e.g. clauses that stipulate number of employees working on a project) may also increase communication and coordination of actions (Chen and Bharadwaj 2009; Faems et al. 2008).

In the face of environmental uncertainty, formal contracts perform an adaptation function in that they allow for adjustments resulting from market changes, or from learning endogenous to the exchange (Schepker et al. 2014). In such cases contracts are used as broad frameworks that leave room for ex post adjustment of investments given that continuity of relationships is valued (Ménard and Valceschini 2005; Mouzas and Ford 2006). Contractual provisions that perform an adaptation function include contingency planning clauses (Argyres et al. 2007; Luo 2002), clauses for price adjustments, as well as provisions for renegotiation of key terms (e.g. resources or budget) at regular intervals to account for environmental changes (Schepker et al. 2014; Crocker and Reynolds 1993). 
In addition to the above, a subtler functionality of contracts has been proposed in the literature. Contracts can also perform a learning function insofar as exchange- and partnerspecific learning, joint improvements and efficient collaboration methods developed during prior exchanges are explicated and embodied into renewed agreements (Mayer and Argyres 2004; Coltman et al. 2009). This process may also lead to more detailed contracting over time affecting specific contractual clauses (see Vanneste and Puranam 2010; Ryall and Sampson 2009). The learning function is closely associated with the codification function in that lessons learned regarding the exchange and the partner are essentially codified through successive agreements. In this sense, learning and codification complement each other and contracts serve as repositories of knowledge (Mayer and Argyres 2004). However, the codification function is broader in scope referring also to (temporarily) stabilised exchange definitions and goals in newly-formed relationships (Selviaridis and Spring 2010).

The safeguarding, coordination and adaptation functions of contracts can either complement or substitute each other depending on the types of contractual clauses invoked, and the broader relationship frame within which contracts are used (Schepker et al. 2014; Collins 1999). Lumineau and Malhotra (2011), for instance, argue that coordination and safeguarding functions serve as complements during dispute resolution when a 'mind set of aligning interests' dominates. Safeguarding provisions may substitute for coordination or adaptation ones when relationship continuity is not valued and litigation action is the preferred option to deal with a breach of obligations (Collins 1999). Existing research, nonetheless, provides scant empirical insights into when (i.e. under which conditions) contracts perform safeguarding, coordination and adaptation functions in ways that reinforce relational mechanisms, and how (see Cao and Lumineau 2015; Schepker et al. 2014).

In sum, the literature review suggests that perceived uncertainty and relational experience have a bearing on the design and functionality of formal contractual provisions, to the extent 
these dominate over, or used as complements to, relational mechanisms. In addition to safeguarding investments, formal contractual provisions may perform codification, coordination, adaptation and learning functions in exchange governance. The empirical study presented in the following examines these functions in the context of logistics outsourcing.

\section{Research method}

A multiple-case design was adopted since there is limited empirical evidence of what functions contractual provisions perform in logistics outsourcing governance. Hence, case-based research was deemed appropriate for gaining in-depth empirical insights and developing theory (Voss, Tsikriktsis, and Frohlich 2002) i.e. propositions regarding the functions of contracts in relation to perceived uncertainty and relational experience. Case study research was also suitable in terms of the theory-method link (Dubois and Araujo 2007). In particular, 3PL is conceptualised as a dynamic process entailing exchange adaptation, experience and knowledge accumulation over time. Case-based research was appropriate for retrospectively studying (Leonard-Barton 1990) how specific contractual provisions functioned in managing and adapting service exchanges and how they interacted with partner-specific experience accumulation, collaboration, and trust effects.

The research entailed a 'theory-matching' process of iterating between existing literature and empirical evidence (Ragin 1992). The analytical frame, empirical research and cross-case analysis were thus co-evolving to match empirical evidence with literature (Dubois and Gadde 2002) and develop theory regarding contract functions. More specifically, the initial interviews challenged the reported dominance of relational mechanisms and stressed the role of contracting in governing 3PL exchanges. Literature on contractual governance and TCE was subsequently reviewed to include in the preliminary analytical frame, and to empirically examine how perceived uncertainty and relational experience can influence contract design and functionality. 
That frame directed further data collection and analysis (Dubois and Gadde 2002) regarding contract functions in the studied cases.

Four cases of 3PL contractual relationships were selected based on theoretical considerations (Dubois and Araujo 2007), i.e. on perceived uncertainty and relational experience attributes. Table 1 presents information about the contractual relationships in focus and the levels of perceived uncertainty and relational experience that the cases exhibited. It is noted that cases A, B and C concern the same LSP and its service contracts with three different customers. It was envisaged that the (contrary) replication logic (Yin 2003) would help identify theoretically important similarities and differences regarding the functions that contractual provisions performed. The process of case selection was in line with the iterative nature of the research process (Ragin 1992). More specifically, the first two cases (cases A and B) exhibited high levels of relational experience and trust building effects based on successful past exchange experiences. However, they differed in terms of perceived uncertainty and service complexity. These insights were used to sample two further cases (cases C and D) in close consultation with key contacts of the LSP companies. These cases were chosen because contracting parties had no trading history and limited relational experience. Subsequent analysis suggested differences between those two cases in terms of perceived uncertainty and service complexity.

\section{[Insert Table 1 about Here]}

\subsection{Data collection and analysis}

Data were collected through two main sources. Review of organisational documents (notably contracts agreements, performance evaluation records, minutes of meetings and emailexchanges) was triangulated (Yin 2003) with 38 semi-structured interviews both with service provider and customer managers from multiple functions (Sales, Commercial, Operations and 
IT from providers' side; Logistics, Purchasing and Customer Services from customers' side). The interview guide and the list of interviewees are provided in Appendices 1 and 2 respectively.

Documents and archival records such as meeting memos and email exchanges between provider and customer managers proved crucial in following up and resolving contrasting interview accounts of certain exchange events (e.g. issues during negotiations and impact on contract design). The interviews, whose average duration was approximately an hour, covered both contractual and relational aspects of logistics outsourcing governance e.g. the design and role of formal contracts and the level of trust and collaboration. They also covered multiple exchange stages (i.e. specification, supplier selection, contacting and post-contract execution and evaluation of exchanges). Real time accounts of post-contract execution and evaluation and related adaptations were combined with retrospective data (Leonard-Barton 1990) which helped to reconstruct key events leading up to contract agreement. All but three interviews were recorded and transcribed. In those instances, where interviewees did not permit recording, detailed notes were taken and followed up immediately after the interview to maximise data accuracy and comprehensiveness.

Data analysis was conducted in parallel with data collection with the aid of the ATLAS.ti software to organise and manage interview transcripts, notes and archival records. The evolving analytical frame informed both within- and cross-case analyses and guided data coding, which was iterative in nature (Ragin 1992). Initially, open coding (Strauss and Corbin 1990) was used to conduct analysis at the case level. This resulted in in-depth understanding of how, and to what extent, certain contractual clauses performed a safeguarding, codification, safeguarding, coordination, adaptation, or learning function. The code manager within ATLAS.ti was used to assign codes to transcribed interviews and document sections based on extant theory (e.g., 'performance review', 'service adaptation'). 
As a next step axial coding (Strauss and Corbin 1990) was used to group codes into higher-level categories (e.g. 'coordination'). The codes were also refined to reflect emerging links between attributes and contract functions (e.g., 'perceived uncertainty and coordination'). Cross-case comparisons helped to identify patterns of contract functions and their influence by perceived uncertainty and relational experience. Manually constructed cross-case tables (Miles and Huberman, 1994), the main of which are provided in Sections 4 and 5 aided the cross-case analysis. The analysis did not reveal any consistent patterns regarding the prominence of specific functions across exchange stages. Although coordination and adaptation functions were more relevant to the post-contract execution and evaluation stage (as expected), no specific patterns were found regarding the safeguarding, codification and learning functions. The data did not allow for drawing definitive links between contract functionality and exchange stages, and further research is needed in this respect.

\subsection{Case study quality criteria}

Four criteria were applied to ensure methodological rigor (Yin 2003). Internal validity was tackled through using different theoretical lenses (TCE and relational exchange governance) to interpret cross-case findings (Gibbert, Ruigrok, and Wicki 2008). Another way was representing the data in tabular forms (see Sections 4 and 5) to facilitate within- and cross-case analyses (Miles and Huberman 1994). Construct validity was ensured through: (a) triangulating retrospective accounts of exchange events with documents (Schwenk 1985) and real-time data (Leonard-Barton 1990) on exchange adaptations; (b) conducting interviews with provider and customer managers from various functions to compare and contrast their views (Huber and Power 1985) and complement data on exchange aspects that provider/ customer interviewees lacked knowledge of (see Appendix 2); (c) selecting multiple informants who either served a key role throughout the exchange process or were involved in specific stages (Golden 1992); 
(d) sending written case reports back to prime contacts for feedback and accuracy checks (Voss et al. 2002); (e) obtaining feedback from peer researchers on tentative conclusions, at regular intervals (Gibbert et al. 2008). External validity was addressed by collecting rich data about the 3PL contractual relations in focus so that readers could potentially relate to and 'transfer' findings to other contexts (Voss et al. 2002). Also, by defining specific dimensions (perceived uncertainty and relational experience) based on which the cases were selected to achieve analytical generalisation (Gibbert et al. 2008). Finally, reliability concerns were minimised through: (a) developing and using an interview guide for data collection across cases, see Appendix 1 (Yin 2003); (b) developing and continuously updating the ATLAS.ti database (interview transcripts and quotations, codes, memos) to ensure the full documentation of the data analysis procedure (Voss et al. 2002); (c) creating an interviewee database (Miles and Huberman 1994), see Appendix 2.

\section{Analysis of the cases}

This section analyses the four cases, focusing on the functions that the formal contractual provisions perform in logistics outsourcing governance. The analysis is aided by Tables 2 and 3 which summarise the key findings.

[Insert Table 2 about here]

[Insert Table 3 about here]

\subsection{Case A}

This case concerns a renewed contract for warehousing and distribution, installation and demonstration of office equipment products. The case exhibited extensive perceived 
uncertainty and relational experience (for details see Table 1). The customer perceived the retendering process as uncertain due to loss of logistics know-how. As the customer's Logistics Contract Director admitted: “[...] managing supply and demand is seen as core competence, but with regard to physical logistics activities we don't have the level of expertise required". However, the provider's in-depth knowledge of customer requirements and the reference to successful past collaboration offset the customer's perceived complexity of the service and led to a rather complete contractual specification at the renewal point, with minimum deviations or disputes regarding reward distribution ex post. The 'assignment specification' appended to the main agreement codified the required service activities, processes and resources (see Table 2). A cost-plus payment mechanism was designed to address the customer's uncertainty regarding service requirements and allowed for monthly variations in resource levels and costs. The agreement also stipulated financial penalties for service failures attributable to provider, and excluded the actions of the other parties such as the customer (e.g. product installation failure due to production defects). Such penalties were escalating according to the failure extent (\%) and significance of Key Performance Indicators (KPIs). An exit clause was also included to safeguard assets and allocate liabilities. Short-term vehicle leases were imposed to reduce customer liabilities in case of exchange termination (Table 3).

The contract provided for regular performance review meetings. The customer's perceived uncertainty resulted in provisions for monthly review meetings to monitor logistics resource utilisation and associated costs. The monthly reviews were also performative in that they helped to identify service improvements and instigated coordinated actions by the two parties (Table 3). The contract also established formal communication channels. However, due to extensive relational experience the exchange parties relied mostly on informal mechanisms such as strategic reviews and joint projects at the operational level to set improvement targets (e.g. improving installation success rate). A 'services variation' clause offered the option to 
adjust activity and resource levels. This provision was not used, though, partly because of the provider's good understanding of operational realities, and partly because of the payment mechanism. As the provider's Business Development (BD) General Manager put it: “The contract is open-book [...] so if there are variations, they tend to be dealt with at an operational level, rather than in a detailed contractual way".

During the previous ten-year contract term the parties focused on developing the solution (e.g. product assembly and installation activities) and investing in a larger UK central warehouse. The activity and resource scope expansion during the previous exchange period were contractually dealt with through agreement addendums and appended letters that formed the basis for negotiating the renewed deal. This process reflected a lot of learning, cost efficiencies and service improvements. These improvements (most of which resulted from extra-contractual joint projects) were capitalised and translated into stricter service levels (e.g. product installation success rate) under the renewed contract.

\subsection{Case B}

This case refers to a three-year renewed contract for distribution of paint products, with limited perceived uncertainty and extensive relational experience (see Table 1). The service exchange definition was codified in the 'service specification' schedule of the contract, detailing the required activities and resources. The service processes and performance levels were described in less detail. For instance, a single service level target of $99.8 \%$ On-Time In-Full (OTIF) deliveries was agreed on the basis of the previous positive exchange experiences (see Table 2). The mutual understanding of operational issues resulted in minimum deviations from the contractual specification schedule ex-post. The $99.8 \%$ delivery target was not linked to financial penalties in cases of provider non-compliance (Table 3) due to relational experience and customer trust on provider competences. The customer's Commercial Buyer confirmed that: 
"They [provider] had the ability to do the job, and a proven track record". However, the contract established the provider's obligation to identify and analyse its service failures and implement corrective actions accordingly.

The contract also included an early termination clause (Table 3) as it became apparent during the negotiations that the central warehouse had to be relocated. The implications of such relocation in terms of transport network design, resources and costs were difficult to predict at the time and hence parties decided to include safeguards against the perceived uncertainty of a sub-optimum location decision. As the provider's Commercial Manager explained: “[ ...] we had to come up with some wording that would enable potentially an early termination of the contract if we couldn't cope with an alternative solution that was acceptable". Customer interviewees also explained that the early termination clause offered protection against potentially inappropriate increase of costs and prices. From the provider's side, uncertainty was addressed through a provision for upward adjustment of provider's operational charges, on the condition that such cost increases would be demonstrable (Table 3). This clause also explicated allocation of exchange costs and rewards, but it was not used.

The contract payment mechanism was based on a combination of fixed and variable charges. An annual service budget, options for annual cost renegotiations and quarterly performance reviews were also catered for in the contract. In addition to formal monitoring and communication provisions, the parties exchanged information through extra-contractual strategic reviews and efficiency improvement projects. For example, the provider worked outside the scope of its contractual obligations to reduce delivery frequency levels (from fiveto three-day deliveries per week) and transport costs without affecting end-customer service levels. The contract also allowed for adaptation of activity and resource levels and costs (see Table 3). In retrospect, this clause was not used due to limited deviations from contract specification ex post. 
All cost and service improvements (e.g. delivery and product loss/ damage) were considered during contract renewal. A previously-used clause specifying conditions upon which financial penalties would apply for under-performance (e.g. delivery target) was excluded from the renewed contract due to trust in provider's competence and proven delivery performance. The renewed contract also reflected the gradual reduction of logistics resources (closing down UK warehouses and cross-docks) as part of strategic reviews and cost-reduction projects. Knowledge accumulated during past exchanges was used to renegotiate provider liability limits for lost and damaged products (in litres of paint per annum). The provider agreed to reduce liability limits on the grounds that past performance reviews showed that there was a low product damage record (Table 3).

\subsection{Case C}

This case concerns a contract for warehousing, cross-docking, call centre services and home deliveries of furniture products. The case exhibited extensive perceived uncertainty and limited relational experience (see Table 1). The extensive environmental uncertainty for both parties meant that the exchange was broadly codified through the service specification schedule putting emphasis on resources and logistics volumes based on forecast sales. Specifications of processes and systems were incomplete as several requirements were evolving (Table 2). Certain clauses catered for the logistics provider's perceived uncertainty regarding the furniture retailer's UK venture. A 'third party guarantor' clause provided safeguards against provider's non-payment risks (Table 3). In addition, the provider's Commercial Manager confirmed that "[...] the contract dictates that that we are appointed as an exclusive contractor for this 8-year period, so they can't actually use another $3 P L[\ldots]$ in case they need more logistics resources in the future, we will provide those”. 
The agreement also included an early termination clause and defined allocation of assets and liabilities in case of the failure of the customer's UK venture. It also imposed one-year warehouse leases to facilitate potential termination and delimit the customer's capital commitments in case of termination. The early termination clause was requested by the provider due to its dedicated investments (distribution centre) and capacity commitments for the specific customer. Given the customer's evolving requirements and the perceived uncertainty regarding the realisation of forecast sales and logistics volumes, this exit clause safeguarded against associated financial risks. The open-book, cost-plus mechanism also helped to address this uncertainty and provided safeguards against financial losses arising from the deviations between forecast resource levels and costs and actual ones.

The contract defined several KPIs (e.g. 99.5\% on time delivery) linked to financial penalties to protect the customer. It also linked these targets with monthly and quarterly meetings to review performance (Table 3). The monthly review meetings proved instrumental to jointly identifying major discrepancies between forecast and actual logistics volumes six months after exchange commencement, and to adapt the service. As the provider's Senior Operations Manager explained, "[...] the solution was adapted because we have implemented a logistics solution for a far greater demand in terms of volume, so our client's expectation was that they would achieve a higher level of sales within their stores which in turn would mean a higher level of activity for ourselves". Such adaptation was enabled through the "service variations' and renegotiations clauses (see Table 3). These were called upon to reduce activity and resource levels (e.g. warehouses and trucks) by 50\% in line with actual sales levels. This process was facilitated by the one-year break clauses included in the warehouse leasing agreement. According to provider interviewees, this resource adaptation ensured that the customer was not losing money and that the exchange was economically viable in the longterm. The expectation at that time was that the relationship would continue. 
These resource and cost reductions were reflected in the contract through schedule amendments (service specification, costs and annual budget). In addition, the parties realised that the original payment mechanism was not viable. In particular, the provider's fee was fixed as a percentage of annual budgeted costs (rather than actual costs). Considering the overestimated first year's budget, that meant that the provider was gaining a greater proportion of the budget as a management fee causing cash flow problems to the customer. The review project was thus perceived by provider interviewees as an act of fairness/justice towards the customer to minimise its loss. The payment mechanism was amended to a fixed fee as percentage of actual operational costs to ensure that further deviations from the (revised) sales forecast and logistics budget would not cause financial imbalances. The revised payment mechanism was also reflected in the contract through schedule amendments.

\subsection{Case D}

This case refers to a five-year contract for distribution of industrial minerals (e.g. sand and soda ash). It exhibited limited perceived uncertainty and relational experience (Table 1). The limited relational experience meant that the service exchange was only broadly codified in the 'statement of work' (SOW) schedule appended to the contract. The exchange parties focused on resource and cost savings resulting from restructuring the transport operation (e.g. reducing the number of distribution vehicles and trailers as well as 'empty running' of vehicles) and put less emphasis on service processes and activities (Table 2). The contract laid out a clear process for the distribution of financial rewards by including an incentive (savings-sharing) mechanism according to which the parties agreed to share logistics cost savings that the provider would generate by restructuring the transport operation. The relevant clause stipulated a 50/50 split of any savings achieved against the agreed budget, above a certain monetary threshold. Deviations from the specified KPI targets (e.g. 98\% delivery timeliness) were linked to financial penalties 
set as fixed monetary sum per provider failure as well as the provider's responsibility for implementing rectification plans. The contract also specified material breach conditions upon which the customer could terminate the contract. These included the failure to achieve KPIs threshold for three months or the failure to meet any single KPI standard for six consecutive months.

The formal contract also provided for quarterly reviews of service performance and costs and frequent communications. The contract clause 'cooperation and relationship management' provided for "frequent contact and weekly meetings between the provider's relationship manager and the client's contract manager" on top of the formal quarterly reviews and also referred to the need for parties to "work together on the spirit of cooperation and trust to create a mutually beneficial relationship". These weekly meetings were useful to resolve operations issues, as the customer's Customer Services Manager put it: [...] I am talking to [the provider] about problems where deliveries haven't been made on time, good customers have specific requirements that they struggle to meet, and just generally the management of problems, so the day to day management of it"”.

The clause 'budget, change to charges and services' set out broad guidelines for service adaptations and revisions of the distribution of financial outcomes (rewards). According to the agreement, resource and operating method adaptations could be requested by either party in writing, and parties should examine also implementation and cost implications of the proposed changes. The cost model (based on which budgets and savings were to be measured) was also subject to review and renegotiation via relevant clauses (see Table 3). The 'budget, change to charges and services' clause was called upon when it became evident that actual resource use and costs deviated from the set budget, creating cost savings measurement and provider undercompensation problems. As the provider's Managing Director explained, “[...] they [customer] didn't really know what their logistics costs were, I mean savings were evident when we took 
over the operation but there was no way to know that, they didn't know how to benchmark that internally. We had serious problems agreeing on what these savings were and how much of that was due to [our] effort". The SOW did not allow for volume and price variations per operating site and exacerbated the difficulties of measuring cost savings and agreeing on provider remuneration (as the incentive fee was linked to savings). The clause enabled such adaptations to the payment model and distribution of cost savings.

Amendments of the cost model (based on cost per tonne charges) and the payment mechanism (provider fee as fixed $\%$ of annual cost per tonne budget and no longer linked to any generated savings) were implemented due to expectations of continuing trade and were reflected in the revised SOW (Table 3). Under the adjusted charging structure, the service became financially viable for the provider.

\section{Discussion}

This section discusses the observed functions that contractual provisions perform in relation to perceived uncertainty and relational experience. The findings confirm previous studies stressing a codification function (Lumineau et al. 2011; Selviaridis and Spring 2010) as parties arrived through the contracting process at a mutually agreed service definition which was reflected in the specification schedules (Table 2). However, such codification was limited to service activities, resources and performance levels to enable exchange commencement and did not include broader roles and responsibilities or exchange contingencies (Mayer and Argyres 2004; Blomqvist et al. 2005). In addition, the level of detail and completeness of such service codification varied. In cases of extensive relational experience (cases A and B) the contractual specification appears to be rather complete in the sense that there were minimum deviations from it ex post. Service specification schedules can be significantly adapted during contract execution when relational experience is limited (cases C and D). 
These findings confirm prior studies suggesting that contract specification schedules (assignment specifications, SOW and SLAs) function as temporary codification devices (Selviaridis et al. 2011; Lindberg and Nordin 2008). Codification of service activities, resources and performance levels is more accurate and 'stable' when partners have already developed good understanding of service operations realities and one another's requirements, rather than when such knowledge is absent and the counterparts rely on invalid assumptions to specify and design service delivery (Terho et al. 2012; Tuli et al. 2007). However, it is recognised that broader roles and responsibilities of the counterparts can also be codified during prolonged contracting processes, even when there is limited relational experience (Lumineau et al. 2011). Overall, it is proposed:

P1: Service specification contract schedules perform a codification function by accurately codifying logistics service activities and processes, resources and performance levels when relational experience is extensive.

Several analysed contractual provisions performed a safeguarding function (see Table 3) by protecting parties against potential opportunism and financial risks (Argyres and Mayer 2007). In particular, the findings stress the role of the contract payment mechanism, in addition to other provisions, in managing complexity and uncertainty in service exchanges (Roehrich and Lewis 2014; Kern and Willcocks 2000). In the cases of extensive perceived uncertainty and service complexity (cases A and C) an open-book, cost-plus charging mechanism was used to hedge against financial risks and adjust costs according to actual operational expenditure. On the other hand, in cases with limited perceived uncertainty and service complexity (cases B and D) the parties did not opt for an open-book mechanism. The above suggest that perceived uncertainty related to complex and evolving service requirements and changes in the exchange environment (Kreye et al. 2015) may motivate contracting parties to adopt more flexible 
payment mechanisms in formal contracts so as to safeguard against financial risks more effectively (Corts and Sigh 2004; Kalnins and Mayer 2004). It is thus proposed:

P2: Open-book, cost-plus payment mechanisms perform a safeguarding function in logistics service exchanges by allowing parties to hedge against financial risks when perceived environmental uncertainty is extensive.

The findings also support prior studies stressing the safeguarding function of termination rights (Schepker et al. 2014). These clauses were perceived by several interviewees as an important safeguarding tool as they allowed exiting the exchange relationship in case of poor provider performance or customer failure to pay on time. In all four contracts such rights also catered for allocation of remaining logistics asset liabilities at the termination date. Compared to the extant literature (Lumineau and Malhotra 2011; Argyres and Mayer 2007), the empirical study provides a more nuanced understanding of how early termination rights are established in response to behavioural uncertainty and perceived risks of opportunism in order to safeguard against financial losses. It is proposed:

P3: Provisions for early termination of logistics service exchanges perform a safeguarding function by hedging against potential opportunism and associated financial losses when perceived behavioural uncertainty is extensive.

The studied contracts also performed a coordination function by setting up and using provisions to review and monitor service performance and costs against the set standards. In addition, provisions for formal communications and information exchange meetings were established and used in order to resolve operational issues or any other concerns arising during the course of the exchange (see Table 3). Compared to the existing literature (Schepker et al. 2014; Chen and Bharadwaj 2009; Poppo and Zenger 2002), the findings offer refined insights regarding the high frequency of the stipulated performance review meetings and formal communications. More specifically, in cases of extensive perceived uncertainty (cases A and 
C) arising specifically from service complexity (Kreye et al. 2015), contracts also stipulated monthly reviews in addition to quarterly and annual ones. These more frequent formal reviews were deemed appropriate by parties in order to identify and resolve issues related to service levels and escalating costs in a coordinated way. It is therefore proposed:

P4: Contractual provisions for frequent performance reviews perform a coordination function by instigating coordinated action to improve logistics service exchange performance when perceived uncertainty arising specifically from service complexity is extensive.

The findings also suggest that contractual provisions for service adjustment and renegotiation rights performed an adaptation function during contract execution (Table 3). Although specific contingency planning clauses (Argyres et al. 2007; Luo 2002) were not evident, clauses regarding services variations and cost and price renegotiations (Schepker et al. 2014; Crocker and Reynolds 1993) proved useful in the cases exhibiting limited relational experience. Specifically, the 'services variations' and 'budget, changes to charges and services' clauses were called upon to adjust the service activity and resource levels and the allocation of exchange costs and rewards. Such provisions were also included in cases exhibiting extensive relational experience, but they were not invoked since exchange-specific knowledge (e.g. volumes, resource use and costs) resulted in minimum deviations from the contractual specification ex post. The findings stressing the role of relational experience are counterintuitive given that the adaptation function of contracts is often seen as a response to environmental uncertainty (Schepker et al. 2014; Ménard and Valceschini 2005), rather than a means to manage limited partner- and exchange-specific knowledge. It is thus proposed:

P5: Clauses of service variations and provisions for renegotiations perform an adaptation function by allowing contracting parties to adapt the logistics service exchange ex post when relational experience is limited. 
The studied contracts performed a learning function, albeit to a limited extent. In cases of extensive relational experience, learning about efficient collaboration methods, service improvements and provider competences was only partly reflected or embodied into renewed contracts (Coltman et al. 2009; Mayer and Argyres 2004) through schedule amendments (Table 3). Hence, no definitive conclusions can be drawn regarding the learning function of logistics service contracts and more specifically the impact of accumulated inter-firm learning on contract extensiveness (Vanneste and Puranam 2010; Ryall and Sampson 2009). However, it is worth noting the role of competence-based trust (Sako 1992), as opposed to trust originating in social bonds or the existence of formal controls (Vanneste and Puranam 2010; Nooteboom et al. 1997), in mediating the safeguarding function of contracts. Extensive relational experience may lead to customer trust in provider competences (but not necessarily so) based on prior positive exchange performance. In such instances (see cases A and B) competence-based trust can be an alternative explanation for the reluctance to rely on detailed contracts (Kreye et al. 2015) and safeguarding provisions e.g. penalty clauses.

Table 4 summarises the findings on the functions that contractual provisions perform in relation to perceived uncertainty and relational experience, which suggest a number of research implications. First, the empirical study contributes to the existing logistics outsourcing literature, which has hitherto emphasised the role of relational mechanisms (Marasco 2008; Moore and Cunningham 1999), by unpacking the multiple functions that specific contractual provisions perform in governing logistics outsourcing exchanges. More specifically, specification schedules, payment mechanisms, (early) termination rights, provisions for frequent performance review and information exchange meetings, service variations clauses, and renegotiations provisions perform codification, safeguarding, coordination and adaptation functions under different levels of perceived uncertainty and relational experience (see propositions). Far from having limited functionality or resulting in lack of trust (Halldórsson 
and Skjøtt-Larsen 2006; Lambert et al. 1999), formal contracts can be used to coordinate and adapt service provision in response to environmental changes, and help codify the service exchange and partner- and exchange-specific learning.

\section{[Insert Table 4 about Here]}

In addition, the study builds upon recent efforts to examine the potential role of formal contracts in managing service complexity (Benedetinni and Neely 2012) in exchange relationships. Such literature argues effectively for the impact of complexity on contract design; higher complexity may often lead to more detailed contracts in terms of clauses protecting against opportunism (Roehrich and Lewis 2014). However, simplified contracts coupled with relational capabilities may be more effective, and indeed less detailed contracts may be used (Kreye et al. 2015). These studies tend to focus on the safeguarding function of contracts; increasing service complexity may require more sophisticated contracts in terms of detailed clauses and contingencies to safeguard against risk and opportunistic behaviour (e.g. Roehrich and Lewis 2014; Kern and Willcocks 2000). This paper adds to this perspective by suggesting that the functionality of contracts extends beyond establishing safeguards (Spring and Araujo 2014). The empirical study examines also how coordination and adaptation-oriented provisions help in managing service complexity and associated uncertainty.

The findings offer empirical insights regarding when (i.e. under which conditions) relational mechanisms and formal contractual provisions complement or substitute each other to effectively govern exchnages, an issue that has recently attracted attention (see Cao and Lumineau 2015; Schepker et al. 2014; Weber, Mayer and Wu 2009). The study demonstrates how formal contracts can perform a codification, coordination or adaptation function under different levels of perceived uncertainty and relational experience. More pointedly, it examines 
when contracts perform codification, coordination and adaptation functions and the ways these interact with relational mechanisms. Specifically, service specification schedules, performance review and communication provisions, service variations clauses, and renegotiation provisions help to reinforce collaboration methods, information sharing patterns and trust, and even codify effective working methods and service improvements.

The findings also present implications for the effects of learning and trust on contract design and extensiveness (Vanneste and Puranam 2010; Ryall and Sampson 2009; Reuer and Arino 2007) by highlighting the role of competence-based trust. Extensive relational experience may lead to competence-based trust, as customers learn about their providers and benefit from performance improvements. This can in turn lead to less detailed contracting and removal of safeguarding clauses (e.g. penalties for service failures). However, extensive relational experience does not necessarily and automatically lead to competence-based trust and less detailed contracts; it might actually have the opposite effect (i.e. more detailed safeguarding provisions) if providers face challenges in delivering performance improvements ${ }^{1}$. In contrast to the extant literature (Vanneste and Puranam 2010; Chen and Bharadwaj 2009), this study suggests that it is trust based on partner competences to deliver the requested performance (Sako 1992), rather than on social bonds or existing contracts (Nooteboom et al. 1997), that may mediate the safeguarding function of contracts. No definitive conclusions can be drawn, though, and further research is needed to examine the impact of competence-based trust on contract extensiveness.

\section{Conclusions}

The extant logistics outsourcing literature emphasises relational mechanisms and has paid less attention to the role of formal contracts in governing exchanges. This paper empirically

\footnotetext{
${ }^{1}$ I am indebted to one of the anonymous reviewers for this insightful point.
} 
examines the multiple functions that contractual provisions perform in service exchange governance. The developed propositions link four contract functions (codification, safeguarding, coordination, and adaptation) to specific provisions: specification schedules, payment mechanisms, (early) termination rights, frequent performance review and inter-firm communication provisions, service variations clauses and renegotiation provisions. Contracts also appear to perform a learning function, though to a limited extent.

The study presents three main research contributions. First, it unpacks the functions of contracts in exchange governance, an issue that has hitherto been underplayed in logistics outsourcing research (Marasco 2008). The study empirically demonstrates how specific provisions and clauses are used to codify the service exchange, to safeguard parties against perceived risks and opportunities, to coordinate their actions to improve service delivery, and to adapt the service exchange in response to environmental changes. Second, the study builds upon recent efforts (Kreye et al. 2015; Roehrich and Lewis 2014) to examine whether, and how, contractual safeguards contribute to managing (service) complexity. The paper adds insights by extending its analysis beyond the safeguarding function, and stressing also how contracts can be used to coordinate and adapt service exchanges in the face of service complexity and associated uncertainty. Third, the study contributes to the governance literature which has recently turned its attention to specific conditions (when) affecting the interplay of contractual and relational mechanisms (Cao and Lumineau 2015). It does so by offering insights into how specific contractual provisions that perform codification, coordination and adaptation functions interact with collaboration and trust, under different levels of perceived uncertainty and relational experience. 


\subsection{Managerial implications}

Managers of customer and provider firms involved in logistics services contracting should consider the specific conditions upon which certain contractual provisions and their associated functions should be stressed to improve exchange effectiveness. Under high levels of service complexity and uncertainty, managers should deploy formal contracts not only as safeguards, but also as coordination devices. More specifically, managers can embed into their contracts and instituationalise routines for frequent performance review meetings, whereby the counterparts exchange information regarding service delivery, identify operational issues and initiative corrective actions to resolve them in a coordinated way. Similarly, under high levels of environmental uncertainty and limited knowledge of the counterart's business requirements, provisions for variations in service activity and resource levels (adaptation-oriented provisions) should be used in tandem with payment mechanisms that allow for flexibility in monthly costs and prices (e.g. open book cost-plus) to protect parties against financial losses arising from variation in demand and service volumes.

Service provider managers should also be aware that their track record of performance and customer trust in the firm's competences may result in customer firms undermining the safeguarding function of formal contracts in exchange governance, and refrain from using legal and economic safeguards. The contract can be used instead as a framework for inter-firm collaboration, allowing for coordinated actions to improve performance and adjust service delivery in response to changes in the market or business environment, and for codifying effective collaboration and service improvement methods. However, a key caveat here is that there needs to be internal alignment between managers and legal advisors who are also involved in contract design and interpretation. This often proves to be a problematic area given the legal counsels' mind set and orientation towards safeguarding and the enforceability of formal provisions in the courts of law. 


\subsection{Limitations and future research}

The study presents limitations that should be tackled through future research. First, the role of competence-based trust in the dynamic interplay of contractual and relational governance mechanisms (Cao and Luminaeu 2015; Faems et al. 2008) should be further examined. Trustbuilding based on positive past collaborations and confidence in partner competences (Sako 1992) can lead to less elaborate contracts at the contract renewal point, but additional empirical evidence is required to establish whether competence-based trust can serve as an antecedent of purposeful contractual incompleteness (Poppo and Zenger 2002; Collins 1999). Second, the role of power-dependence relationships in connection to contract design and functionality has not been addressed in this study. Power-dependence aspects may have a bearing in contract functionality, particularly in relation to the assignment of property, decision, and control rights to protect parties with low bargaining power (Schepker et al. 2014; Adegbesan and Higgins 2011). Further empirical research is needed in this respect.

Third, the paper offered scant insights into the prominence of specific contract functions in relation to the exchange timeline. Future studies should attempt to draw links between contract functions and exchange stages e.g. regarding the use of codification and learning functions both during the contracting process and in the contract execution phase. Fourth, further research is needed to understand what sets of contracting capabilities are required specifically to perform the codification, coordination and adaptation functions of contracts, and how these can be developed (Spring and Araujo 2014). This research highlighted these functions (in addition to the safeguarding one) but did not study in detail the associated contracting capabilities and their interplay with relational ones.

Fifth, it is acknowledged that the findings refer to a particular legal-institutional system and service industry (UK logistics industry). The findings could, nevertheless, be generalised to settings of outsourced public services insofar as formal contracts perform multiple functions 
in shaping and governing service exchanges (e.g. see the NHS - DHL Supply Chain contract).

The findings may be less applicable to public infrastructure and complex product-service provision whereby coordination and adaptation tends to rely heavily on relational capabilities (e.g. Hartmann et al. 2014). Future research should test the research propositions through: (a) studying contracts developed within different institutional environments, and their impact on service exchange governance (Oxley 1999), and (b) conducting large-scale surveys covering contractual relationships in diverse settings (e.g. provision of public infrastructure whereby services and capital equipment are integrated into a complex bundle), different service industries or even different segments of a particular industry (e.g. e-freight exchanges). Such an extended programme of research would help develop a more refined understanding of contract functions in service exchange governance.

\section{References}

Adegbesan, J. A., and Higgins, M. J. 2011. "The Intra Alliance Division of Value Created Through Collaboration. Strategic Management Journal 32: 187-211.

Argyres, N., J. Bercovitz, and K. Mayer. 2007. "Complementarity and Evolution of Contractual Provisions: An Empirical Study of IT Services Contracts." Organization Science 18 (1): 3-19.

Argyres, N., and J. Liebeskind. 1999. "Contractual Commitments, Bargaining and Governance Inseperability: Incorporating History into Transaction Cost Theory." Academy of Management Review 24 (1): 49-63.

Argyres, N., and K. Mayer. 2007. "Contract Design as a Firm Capability: An Integration of Learning and Transaction Cost Perspectives." Academy of Management Review 32 (4): 1060-1077.

Badinelli, R., S. Barile, I. Ng, F. Polese, M. Saviano, and P. D. Nauta. 2012. "Viable Service Systems and Decision Making in Service Management." Journal of Service Management 23 (4): 498-526.

Benedettini, O., and A. Neely. 2012. "Complexity in Services: An Interpretative Framework." POMS 23rd Annual Conference, Chicago, Illinois, USA, April 20-23.

Blomqvist, K., P. Hurmelinna, and R. Seppanen. 2005. "Playing the Collaboration Game Right Balancing Trust and Contracting." Technovation 25 (5): 497-504.

Boyson, S., T. Corsi, M. E. Dresner, and E. Rabinovich. 1999. "Managing Effective 3PL Relationships: What Does it Take? Journal of Business Logistics 21 (1): 73-100.

Caniëls, M., C. Gelderman, and N. Vermeulen. 2012. "The Interplay of Governance Mechanisms in Complex Procurement Projects." Journal of Purchasing and Supply Management 18 (2): 113-121.

Cannon, J., R. Achrol, and G. Gundlach. 2000. "Contracts, Norms and Plural Form Governance." Academy of Marketing Science 28 (2):180-194.

Cao, Z. and F. Lumineau. 2015. "Revisiting the Interplay between Contractual and Relational Governance: A Qualitative and Meta-Analytic Investigation". Journal of Operations Management 33-34: $15-42$.

Chen, Y., and A. Bharadwaj. 2009. "An Empirical Analysis of Contract Structures in IT Outsourcing." Information Systems Research 20 (4): 484-506. 
Chen, Y.M., M-J. Goan, and P-N. Huang. 2011. "Selection Process in Logistics Outsourcing - A View from Third Party Logistics Provider. Production Planning \& Control 22 (3): 308-324.

Collins, H., 1999. Regulating Contracts. Oxford: Oxford University Press.

Coltman, T., K. Bru, N. Perm-Ajchariyawong, T. Devinney, and G. Benito. 2009. "Supply Chain Contract Evolution." European Management Journal 27 (6): 388-401.

Corts, K., and J. Singh. 2004. "The Effect of Repeated Interaction on Contract Choice: Evidence from Offshore Drilling." Journal of Law, Economics and Organization 20 (1): 230-259.

Crocker, K. J., and Reynolds, K. J. 1993. "The Efficiency of Incomplete Contracts: An Empirical Analysis of Air Force Engine Procurement". RAND Journal of Economics 24: 126-146.

Datta, P.P. and R. Roy. 2013. "Incentive Issues in Performance-Based Outsourcing Contracts in the UK Defence Industry: A Simulation Study”. Production Planning \& Control 24 (4/5): 359-374.

Dyer, J. H., and H. Singh. 1998. "The relational View: Cooperative Strategy and Sources of Interorganisational Competitive Advantage." Academy of Management Review 23 (4): 660-679.

Dubois, A., and L. Araujo. 2007. "Case Research in Purchasing and Supply Management: Opportunities and Challenges." Journal of Purchasing and Supply Management 13 (2): 170-181.

Dubois, A., and L.-E. Gadde. 2002. "Systematic Combining: An Abductive Approach to Case Research". Journal of Business Research 55 (7): 553-560.

Faems, D., M. Janssens, A. Madhok, and B. van Looy. 2008. "Towards an Integrative Perspective on Alliance Governance: Connecting, Contract Design, Trust Dynamics, and Contract Application.” Academy of Management Journal 51 (6): 1053-1078.

Forslund, H. 2009. "Logistics Service Performance Contracts: Design, Contents and Effects". International Journal of Physical Distribution and Logistics Management 39 (2): 131-144.

Gadde, L.E., and K. Hulthèn. 2010. "Improving Logistics Outsourcing through Increasing BuyerProvider Interaction.” Industrial Marketing Management 38 (6): 633-640.

Geyskens, I., J-B. Steenkamp, and N. Kumar. 2006. "Make, Buy or Ally: A Transaction Cost Theory Meta-Analysis." Academy of Management Journal 49 (3): 519-543.

Gibbert, M., W. Ruigrok, and B. Wicki. 2008. "What Passes as a Rigorous Case Study?" Strategic Management Journal 29 (13): 1465-1474.

Golden, B.R. 1992. "The Past is the Past - or Is It? The Use of Retrospective Accounts as Indicators of Past Strategy." Academy of Management Journal 35 (4): 848-860.

Håkansson, H., and I. Snehota. 2002. "The IMP Perspective: Assets and Liabilities of Business Relationships." In Understanding Business Marketing and Purchasing (3rd ed.), 35-50. Edited by Ford, D. London: Thompson Learning.

Halldórsson, A., and T. Skjøtt-Larsen. 2006. "Dynamics of Relationship Governance in TPL Arrangements: A Dyadic Perspective." International Journal of Physical Distribution and Logistics Management 36 (7): 490-506.

Hartmann, A., J. Roehrich, L. Fredriksen, and A. Davies. 2014. "Procuring Complex Performance: The Transition Process in Public Infrastructure". International Journal of Operations and Production Management 34 (2): 174-194.

Heide, J. 1994. Interorganizational Governance in Marketing Channels." Journal of Marketing 58 (1): 71-85.

Hofenk, D., R. Schipper, J. Semeijn, and C. Gelderman. 2011. "The Influence of Contractual and Relational Factors on the Effectiveness of Third Party Logistics Relationships." Journal of Purchasing and Supply Management 17 (3):167-175.

Huber, G., and D.J. Power. 1985. "Research Notes and Communications - Retrospective Reports of Strategic Managers: Guidelines for Increasing their Accuracy." Strategic Management Journal 6 (2): $171-180$.

Jayaram, Y., and K-C. Tan. 2010. "Supply Chain Integration with Third-Party Logistics Providers." International Journal of Production Economics 125 (2): 262-271.

Kalnins, A., and K. Mayer. 2004. "Relationships and Hybrid Contracts: An Analysis of Contract Choice in Information Technology." Journal of Law, Economics and Organization 20 (1): 207-229.

Kern, T., and L. Willcocks. 2000. "Exploring Information Technology Outsourcing Relationships: Theory and Practice." Journal of Strategic Information Systems 9 (4): 321-350.

Klein-Woolthuis, R., B. Hillebrand, and B. Nooteboom. 2005. "Trust, Contract and Relationship Development." Organization Studies 26 (6): 813-840. 
Knemeyer, A.M., and P.R. Murphy. 2005. "Exploring the Potential Impact of Relationship Characteristics and Customer Attributes on the Outcomes of 3PL Arrangements." Transportation Journal 44 (1): 5-19.

Kreye, M., J.K. Roehrich, and M.A Lewis. 2015. "Servitizing Manufacturers: The Importance of Service Complexity and Contractual and Relational Capabilities". Production Planning \& Control 26 (1415): 1233-1246.

Lambert, D. M., M. A. Emmelhainz, and J. T. Gardner. 1999. "Building Successful Logistics Partnerships." Journal of Business Logistics 20 (1):165-181.

Lazzarini, S., G. Miller, and T. Zenger. 2004. "Order with Some Law: Complementarity versus Substitution of Formal and Informal Agreements". Journal of Law, Economics and Organization 20 (2): 261-298.

Leonard-Barton, D. 1990. “A Dual Methodology for Case Studies: Synergistic Use of a Longitudinal Single Site with Replicated Multiple Sites". Organization Science 1 (3): 248-266.

Lindberg, N., and F. Nordin. 2008. "From Products to Services and Back Again: Towards a New Service Procurement Logic". Industrial Marketing Management 37 (3): 292-300.

Liu, C., H. Tian, J. Sun, and D.D Wu. 2009. "Incentive Contract Design in Competing Distribution Channels". Production Planning \& Control 20 (4): 295-305.

Logan, M. S. 2000. "Using Agency Theory to Design Successful Outsourcing Relationships." International Journal of Logistics Management 11 (2): 21-32.

Lukassen, P., and C-M. Wallenburg. 2010. "Pricing Third Party Logistics Services: Integrating Insights from the Logistics and Industrial Services Literature". Transportation Journal 49 (2): 24-43.

Lumineau, F., M. Frechet, and D. Puthod. 2011. "An Organizational Learning Perspective on the Contracting Process." Strategic Organization 9 (1): 8-32.

Lumineau, F., and Malhotra, D. 2011. "Shadow of the Contract: How Contract Structure Shapes Interfirm Dispute Resolution. Strategic Management Journal 32: 532-555.

Luo, Y. 2002. "Contract, Cooperation and Performance in International Joint Ventures." Strategic Management Journal 23 (10): 903-919.

Lusch, R., and J. Brown. 1996. "Interdependency, Contracting and Relational Behavior in Marketing Channels". Journal of Marketing 60 (4): 19-38.

Marasco, A. 2008. "Third-Party Logistics: A Literature Review". International Journal of Production Economics 113 (1): 127-147.

Masten, S., J. Meehan, and E. Snyder. 1991. "The Costs of Organization.” Journal of Law, Economics and Organization 7 (1): 1-25.

Mayer, K., and N. Argyres. 2004. "Learning to Contract: Evidence from the Personal Computer Industry." Organization Science 15 (4): 394-410.

McNeil, I. 1980. The New Social Contract: An Inquiry into Modern Contractual Relations. New Haven: Yale University Press.

Ménard, C. 2004. "The Economics of Hybrid Organization." Journal of Institutional and Theoretical Economics 160 (3): 345-376.

Ménard, C., and E. Valceschini. 2005. "New Institutions for Governing the Agri-Food Industry." European Review of Agricultural Economics 32 (3): 421-440.

Miles, M.B., and A.M. Huberman. 1994. Qualitative Data Analysis: An Expanded Sourcebook. Newbury Park: Sage.

Moore, K.R., and W.A. Cunningham. 1999. "Social Exchange Behaviour in Logistics Relationships: A Shipper Perspective." International Journal of Physical Distribution and Logistics Management 29 (2): 103-121.

Mouzas, S., and D. Ford. 2006. "Managing Relationships in Showery Weather: The Role of Umbrella Agreements." Journal of Business Research 59 (12): 1248-1256.

NHS Supply Chain. 2016. NHS Supply Chain: About Us. Available at: https://www.supplychain.nhs.uk/about-us/what-we-do [Accessed 10 May 2016].

Nooteboom, B., H. Berger, and N. Noorderhaven. 1997. Effects of Trust and Governance on Relational Risk." Academy of Management Journal 40 (2): 308-338.

Oxley, J. 1999. "Institutional Environment and the Mechanisms of Governance: The Impact of Intellectual Property Protection on the Structure of Inter-Firm Alliances." Journal of Economic Behavior and Organization 38 (3): 283-309. 
Poppo, L., and T. Zenger. 2002. "Do Formal Contracts and Relational Governance Function as Substitutes or Complements?" Strategic Management Journal 23 (8): 707-725.

Ragin, C. C. 1992. "Casing and the Process of Social Enquiry." In What is a Case? Exploring the Foundations of Social Inquiry. Edited by Ragin, C. C., and H. S. Becker, 217-226. Cambridge: Cambridge University Press.

Reuer, J., and A. Arino. 2007. "Strategic Alliance Contracts: Dimensions and Determinants of Contractual Complexity." Strategic Management Journal 28 (3): 313-330.

Rindfleisch, A., and J. Heide. 1997. "Transaction Cost Analysis: Past, Present and Future Applications". Journal of Marketing 61 (4): 30-54.

Ring, P. S., and A. H. Van de Ven. 1992. "Structuring Cooperative Relationships between Organizations". Strategic Management Journal 13 (7): 483-498.

Roehrich, J.K. and M.A. Lewis. 2014. "Procuring Complex Performance: Implications for Exchange Governance Complexity". International Journal of Operations \& Production Management 32 (2): 221-241.

Rossiter-Hofer, A., M. Knemeyer, and P. R. Murphy. 2012. "The Roles of Procedural and Distributive Justice in Logistics Outsourcing Relationships". Journal of Business Logistics 33 (3): 196-209.

Ryall, M.D., and R.C. Sampson. 2009. "Formal Contracts in the Presence of Relational Enforcement Mechanisms: Evidence from Technology Development Projects.” Management Science 55 (6): 906925.

Sako, M. 1992. Prices, Quality and Trust: Inter-firm Relations in Britain and Japan, New York: Cambridge University Press.

Sampson, S. E., and M. Spring. 2012. "Customer Roles in the Service Supply Chain and Opportunities for Innovation". Journal of Supply Chain Management 48 (4): 30-50.

Schepker, D., Y-W., Oh, A. Martynov, and L. Poppo. 2014. "The Many Futures of Contracts: Moving Beyond Structure and Safeguarding to Coordination and Adaptation". Journal of Management 40 (1): 193-225.

Schwenk, C.R. 1985. "The Use of Participant Recollection in the Modeling of Organizational Decision Processes". Academy of Management Review 10 (3): 496-503.

Selviaridis, K., H. Agndal, and B. Axelsson. 2011. "Business Services 'In the Making': (De)stabilization of Service Definitions during the Sourcing Process." Journal of Purchasing and Supply Management 17 (2): 73-86.

Selviaridis, K., and A. Norrman. 2015. "Performance-based Contracting for Advanced Logistics Services: Challenges in its Adoption, Design and Management". International Journal of Physical Distribution \& Logistics Management 45 (6): 592 - 617.

Selviaridis, K., and M. Spring. 2010. "The Dynamics of Business Service Exchanges: Insights from Logistics Outsourcing." Journal of Purchasing and Supply Management 16 (3):171-184.

Selviaridis, K., and M. Spring. 2007. "Third Party Logistics: A Literature Review and Research Agenda." International Journal of Logistics Management 18 (1): 125-150.

Solakivi, T., J. Töyli, and L. Ojala. 2013. "Logistics Outsourcing, its Motives, and the Level of Logistics Costs in Manufacturing and Trading Companies Operating in Finland." Production Planning \& Control 24 (4/5): 388-398.

Spring, M., and L. Araujo. 2014. "Indirect Capabilities and Complex Performance: Implications for Procurement and Operations Strategy". International Journal of Operations and Production Management 34 (2): 150-173.

Strauss A., and J. Corbin. 1990. Basics of Qualitative Research: Grounded Theory Procedures and Techniques. Newbury Park: Sage.

Terho, H., A. Haas, A. Eggert, and W. Ulaga. 2012. "It's Almost like Taking the Sales out of Selling: Towards a Conceptualization of Value-Based Selling in Business Markets." Industrial Marketing Management 41 (1): 174-185.

Tuli, K, A. Kohli, and S. Bharadwaj. 2007. "Rethinking Customer Solutions: From Product Bundles to Relational Processes". Journal of Marketing 71 (3): 1-17.

Ulaga, W., and A. Eggert. 2006. "Value-Based Differentiation in Business Relationships: Gaining and Sustaining Key Supplier Status”. Journal of Marketing 70 (1): 119-136. 
Vandaele, D., D. Rangarajan, P. Gemmel, and A. Lievens. 2007. "How to Govern Business Services Exchanges: Contractual and Relational Issues". International Journal of Management Reviews 9 (3): 237-258.

Vanneste, B., and P. Puranam. 2010. "Repeated Interactions and Contractual Detail: Identifying the Learning Effect.” Organization Science 21 (1): 186-201.

Voss, C., N. Tsikriktsis, and M. Frohlich. 2002. "Case Research in Operations Management." International Journal of Operations and Production Management 22 (2): 195-219.

Wagner, S.M., and R. Sutter. 2012. "A Qualitative Investigation of Innovation between Third-Party Logistics Providers and Customers." International Journal of Production Economics 140 (2): 944958.

Wallenburg, C-M., D. Cahill, T. Goldsby, and M. Knemeyer. 2010. "Logistics Outsourcing Performance and Customer Loyalty: Comparison between Germany and the United States." International Journal of Physical Distribution and Logistics Management 40 (7): 579-603.

Weber, L., K. Mayer, and R. Wu. 2009. "The Future of Inter-Firm Contract Research: Opportunities Based on Prior Research and Non-Traditional Tools". Advances in Strategic Management 26:123145.

Wilding, R., and R. Juriado. 2004. "Customer Perceptions on Logistics Outsourcing in the European Consumer Goods Industry." International Journal of Physical Distribution and Logistics Management 34 (8): 628-644.

Williamson, O. E. 1993. "Calculativeness, Trust and Economic Organization." Journal of Law and Economics 36 (1): 453-486.

Williamson, O. E. 1991. "Comparative Economic Organization: The Analysis of Discrete Structural Alternatives.” Administrative Science Quarterly 36 (2): 269-296.

Williamson, O. E. 1985. The Economic Institutions of Capitalism. New York: The Free Press.

Yin, R.K. 2003. Case Study Research: Design and Methods, Thousand Oaks: Sage.

Zheng, J., J. K. Roehrich, and M. A. Lewis. 2008. "The Dynamics of Contractual and Relational Governance: Evidence from Long-Term Public-Private Procurement Arrangements." Journal of Purchasing and Supply Management 14 (1): 43-54.

Zollo, M., J. Reuer, and H. Singh. 2002. "Inter-organizational Routines and Performance in Strategic Alliances." Organization Science 13 (6): 701-713. 


\section{Appendix 1. The Interview guide}

\section{A. Company Information}

- Interviewee details (name, department, job title and role)?

- Company details (core business, products/services, annual turnover, market share, key customers/suppliers)?

\section{B. Service offering and the business relationship}

- Can you briefly describe the customer's supply chain/logistics structure?

- What is the scope of the 3PL provider's service offering?

- Can you briefly describe the key service activities, processes and resources?

- Can you provide an overview of the customer/provider relationship in focus?

- What are the main sources of uncertainty regarding the management of the customer/provider exchange relationship in focus, if any?

- Can you provide a brief account of the customer/provider relationship history and evolution, if applicable? (key events and milestones)

- To what extent have you developed specific knowledge about the customer's /provider's operations and broader business requirements?

\section{The contracting process}

- Can you provide a brief overview of the contracting process (key events and challenges)?

- Service specification phase/challenges?

- Provider selection phase/challenges?

- Economic and contractual negotiations/challenges?

- Contract development phase/challenges?

\section{The contract}

- Contract agreement: structure and content?

- Provisions in the master agreement?

- Provisions in the contract schedules?

- Service level agreements/KPIs?

- Payment mechanism?

- To what extent are the contractual provisions used to govern the exchange? Why (not)?

- How does the contract function in managing the exchange relationship in focus?

\section{E. Post-contract service delivery}

- Service implementation and ongoing delivery?

- Service performance measurement - any deviations from contract?

- How has the service exchange been adapted, if at all?

- What kind of re-negotiations took place, if at all? How were those perceived and handled?

- What is the role of formal contract in service adaptations and renegotiation?

- How are service adaptations and exchange developments reflected into the formal contract, if at all?

- What is the role of formal contract, as opposed to that of trust, in managing the exchange relationship in focus?

\section{F. Final Questions}

- Relevant organisational documents (e.g. contracts/SLAs)?

- Return back for supplementary questions?

- Suggestions for further research/interviewees? 


\section{Appendix 2. List of interviewees}

\begin{tabular}{|c|c|c|}
\hline Case study & Service provider interviewees & Customer interviewees \\
\hline Case A & $\begin{array}{l}\text { BD Manager (Hi-tech sales team) } \\
\text { BD Manager (Hi-tech sales team) } \\
\text { Divisional Development Manager } \\
\text { Logistics Analyst (Hi-tech sales team) } \\
\text { Commercials General Manager } \\
\text { Logistics Analyst (Hi-tech sales team) } \\
\text { BD Manager (Hi-tech sales team) } \\
\text { Senior Operations Manager } \\
\text { BD Manager (Hi-tech sales team) }\end{array}$ & $\begin{array}{l}\text { Logistics Contracts Director } \\
\text { Logistics Contracts Manager }\end{array}$ \\
\hline Case B & $\begin{array}{l}\text { BD Manager (Industrials sales team) } \\
\text { Logistics Design Manager (Industrials sales team) } \\
\text { Logistics Analyst (Industrials sales team) } \\
\text { Account Director for contract B } \\
\text { Commercials General Manager } \\
\text { Contracts Manager } \\
\text { BD Manager (Industrials sales team) }\end{array}$ & $\begin{array}{l}\text { Logistics Manager } \\
\text { Commercial Buyer }\end{array}$ \\
\hline Case C & $\begin{array}{l}\text { Senior Operations Manager } \\
\text { BD Manager (Home Deliveries) } \\
\text { Commercials General Manager } \\
\text { Senior Business Systems Manager } \\
\text { Logistics Design Manager (Home Deliveries) } \\
\text { Logistics Design Manager (Warehouse Design Unit) } \\
\text { Commercials General Manager } \\
\text { Senior Operations Manager } \\
\text { BD Manager (Home Deliveries) }\end{array}$ & - \\
\hline Case D & $\begin{array}{l}\text { Managing Director } \\
\text { BD Manager } \\
\text { Warehousing General Manager } \\
\text { Account Manager } \\
\text { Account Manager: client contract D } \\
\text { Operations Manager: client contract D } \\
\text { BD Manager } \\
\text { Business Systems Manager } \\
\text { Managing Director }\end{array}$ & Customer Services Manager \\
\hline
\end{tabular}


Table 1. Overview of the cases

\begin{tabular}{|c|c|c|c|c|}
\hline & Case A & Case B & Case C & Case D \\
\hline $\begin{array}{l}\text { Customer } \\
\text { firm }\end{array}$ & $\begin{array}{l}\text { Manufacturer of office } \\
\text { equipment machines (e.g. } \\
\text { copiers and printers) }\end{array}$ & $\begin{array}{l}\text { Manufacturer of paint and } \\
\text { industrial coatings }\end{array}$ & $\begin{array}{l}\text { Retailer of furniture products and } \\
\text { home accessories }\end{array}$ & $\begin{array}{l}\text { Producer of industrial } \\
\text { minerals }\end{array}$ \\
\hline $\begin{array}{l}\text { Service } \\
\text { provider } \\
\text { solution }\end{array}$ & $\begin{array}{l}\text { Warehousing, } \\
\text { distribution, installation \& } \\
\text { demonstration of } \\
\text { machines; machine } \\
\text { networking, testing, pre- } \\
\text { assembly and other value- } \\
\text { add services }\end{array}$ & $\begin{array}{l}\text { Cross-docking \& end- } \\
\text { customer deliveries of paint } \\
\text { and industrial coating } \\
\text { products }\end{array}$ & $\begin{array}{l}\text { Warehousing, cross-docking, call } \\
\text { centre \& home deliveries of } \\
\text { furniture products; light assembly } \\
\& \text { customer collection services }\end{array}$ & $\begin{array}{l}\text { Distribution of sand- } \\
\text { based minerals; the } \\
\text { service scope included } \\
\text { management of } \\
\text { transport sub-contractor } \\
\text { network across the UK. }\end{array}$ \\
\hline $\begin{array}{l}\text { Contract } \\
\text { duration }\end{array}$ & Renewed 3-year contract & Renewed 3-year contract & 8.5-year contract & 5-year contract \\
\hline $\begin{array}{l}\text { Contract } \\
\text { value per } \\
\text { annum }\end{array}$ & $£ 5,5$ million & $£ 3,5$ million & $£ 41$ million & $£ 4$ million \\
\hline $\begin{array}{l}\text { Business } \\
\text { relationship } \\
\text { status }\end{array}$ & $\begin{array}{l}\text { 13-year trading } \\
\text { relationship and prior } \\
\text { exchange experiences. }\end{array}$ & $\begin{array}{l}\text { 22-year trading relationship } \\
\text { and prior exchange } \\
\text { experiences. }\end{array}$ & $\begin{array}{l}\text { Newly-established business } \\
\text { relationship, no prior trading } \\
\text { experience. }\end{array}$ & $\begin{array}{l}\text { Newly-established } \\
\text { business relationship, } \\
\text { no prior trading } \\
\text { experience. }\end{array}$ \\
\hline $\begin{array}{l}\text { Perceived } \\
\text { uncertainty }\end{array}$ & $\begin{array}{l}\text { Extensive; a complex, } \\
\text { multi-functional service } \\
\text { was re-tendered for after } \\
10 \text { years. At the renewal } \\
\text { point, the customer } \\
\text { perceived high } \\
\text { uncertainty in terms of } \\
\text { defining its technical } \\
\text { requirements and grasping } \\
\text { the existing solution } \\
\text { complexity. Its technical } \\
\text { knowledge was eroded } \\
\text { due to turnkey logistics } \\
\text { outsourcing for more than } \\
\text { a decade. Failure to keep } \\
\text { up with technological } \\
\text { changes and decreasing } \\
\text { ability to predict and } \\
\text { specify logistics } \\
\text { requirements. Perceived } \\
\text { risk of opportunism by the } \\
\text { incumbent provider. }\end{array}$ & $\begin{array}{l}\text { Limited; A simple transport } \\
\text { service was re-tendered for } \\
\text { after the previous } 3 \text {-year } \\
\text { agreement. At the contract } \\
\text { renewal point perceived } \\
\text { uncertainty was limited the } \\
\text { service was perceived as } \\
\text { simple and entailed } \\
\text { minimum additional } \\
\text { requirements. Both the } \\
\text { customer and provider were } \\
\text { knowledgeable about } \\
\text { service requirements and } \\
\text { costs. }\end{array}$ & $\begin{array}{l}\text { Extensive; Both parties perceived } \\
\text { the service to be complex. It } \\
\text { entailed operating in a new } \\
\text { market environment (UK) with no } \\
\text { historical volume data and set } \\
\text { supply chain infrastructure. The } \\
\text { customer initially had limited } \\
\text { knowledge of its technical } \\
\text { requirements which were } \\
\text { evolving. The provider had } \\
\text { limited understanding of the } \\
\text { customer's sales and logistics } \\
\text { volume profile and perceived the } \\
\text { situation to be highly uncertain } \\
\text { both financially and operationally }\end{array}$ & $\begin{array}{l}\text { Limited; customer } \\
\text { experienced in } \\
\text { outsourcing transport } \\
\text { services and } \\
\text { knowledgeable about } \\
\text { technical requirements } \\
\text { and service volumes. } \\
\text { Provider developed its } \\
\text { knowledge about } \\
\text { service volume and } \\
\text { resource profile through } \\
\text { a review of the } \\
\text { customer's transport } \\
\text { operation conduced in } \\
\text { advance of the } \\
\text { tendering process }\end{array}$ \\
\hline $\begin{array}{l}\text { Relational } \\
\text { experience }\end{array}$ & $\begin{array}{l}\text { Extensive; collaboration } \\
\text { reinforced by information } \\
\text { and knowledge sharing } \\
\text { routines and multiple joint } \\
\text { projects. High levels of } \\
\text { trust based on prior } \\
\text { experiences and } \\
\text { performance } \\
\text { improvements introduced } \\
\text { over time }\end{array}$ & $\begin{array}{l}\text { Extensive; collaboration } \\
\text { and information sharing. } \\
\text { Trust developed based on } \\
\text { provider good track record } \\
\text { of performance }\end{array}$ & $\begin{array}{l}\text { Limited; no prior exchange } \\
\text { experiences. The contracting } \\
\text { process helped to develop mutual } \\
\text { understanding of goals and } \\
\text { expectations, as well as to refine } \\
\text { service requirements and design } \\
\text { the service based on shared sales } \\
\text { and volume forecasts }\end{array}$ & $\begin{array}{l}\text { Limited; no prior } \\
\text { exchange experiences. } \\
\text { Mutual understanding } \\
\text { of goals and } \\
\text { expectations was built } \\
\text { during the contracting } \\
\text { process }\end{array}$ \\
\hline
\end{tabular}


Table 2. Codification function of logistics service contracts through the specification schedule(s)

\begin{tabular}{|c|c|c|c|c|}
\hline $\begin{array}{l}\text { Specification } \\
\text { Schedule(s) }\end{array}$ & Case A & Case B & Case C & Case D \\
\hline $\begin{array}{l}\text { Activities and } \\
\text { processes }\end{array}$ & $\begin{array}{l}\text { storage, cross-docking, } \\
\text { installation \& demo, } \\
\text { put away per product } \\
\text { type, picking, load } \\
\text { planning }\end{array}$ & $\begin{array}{l}\text { product receipt, cross- } \\
\text { docking, distribution, } \\
\text { product handling, } \\
\text { returns }\end{array}$ & $\begin{array}{l}\text { warehousing, home } \\
\text { deliveries, call } \\
\text { centre service, store } \\
\text { replenishment, }\end{array}$ & $\begin{array}{l}\text { Inter-quarry transport, } \\
\text { customer delivery } \\
\text { scheduling, product } \\
\text { handling }\end{array}$ \\
\hline Resource levels & $\begin{array}{l}\text { Four warehouses; Core } \\
\text { fleet plus } \\
\text { subcontracting during } \\
\text { end-month peak }\end{array}$ & $\begin{array}{l}30 \text { vehicles, one } \\
\text { warehouse; Possible } \\
\text { subcontracting }\end{array}$ & $\begin{array}{l}\text { Five warehouses, } 14 \\
\text { line-haul vehicles; } \\
\text { Subcontract for }>50 \\
\text { miles' home } \\
\text { deliveries }\end{array}$ & $\begin{array}{l}\text { List of vehicles, trailers } \\
\text { and equipment; } \\
\text { Subcontracting possible }\end{array}$ \\
\hline $\begin{array}{l}\text { Volumes and } \\
\text { costs }\end{array}$ & $\begin{array}{l}\text { Based on profile } \\
\text { assumptions; cost-plus } \\
\text { charging; separation of } \\
\text { fixed and variable costs }\end{array}$ & $\begin{array}{l}\text { Based on client delivery } \\
\text { profile; fixed and } \\
\text { variable (pence/mile); } \\
1^{\text {st }} \text { year budget included }\end{array}$ & $\begin{array}{l}\text { Based on client } \\
\text { forecast sales; } 1^{\text {st }} \\
\text { year budget agreed; } \\
\text { cost-plus charges }\end{array}$ & $\begin{array}{l}\text { No reference to specific } \\
\text { volumes; service budget } \\
\text { to be agreed; savings- } \\
\text { sharing }(50 / 50) \text { above } \\
\text { certain } £ \text { sum }\end{array}$ \\
\hline $\begin{array}{l}\text { KPIs/ service } \\
\text { levels }\end{array}$ & $\begin{array}{l}99.5 \% \text { pick accuracy, } \\
99 \% \text { delivery \& } \\
\text { installation success; } \\
95 \% \text { customer contact } \\
\text { success }\end{array}$ & $\begin{array}{l}99.8 \% \text { customer } \\
\text { delivery as joint target }\end{array}$ & $\begin{array}{l}99.5 \% \text { delivery } \\
\text { within time window, } \\
\text { calls answered } \\
\text { within } 78 \text { seconds. }\end{array}$ & $\begin{array}{l}>98 \% \text { delivery } \\
\text { timeliness; }<9 \text { end } \\
\text { customer complaints; } \\
\text { customer volumes as } \\
\text { per order; fleet } \\
\text { utilisation as per budget }\end{array}$ \\
\hline
\end{tabular}


Table 3. Safeguarding, coordination, adaptation, and learning functions of logistics service contracts

\begin{tabular}{|c|c|c|c|c|c|}
\hline Provisions & Function(s) & Case A & Case B & Case C & Case D \\
\hline $\begin{array}{l}\text { Payment } \\
\text { mechanism }\end{array}$ & Safeguarding & $\begin{array}{l}\text { Open-book, cost } \\
\text { plus monthly } \\
\text { charges }\end{array}$ & $\begin{array}{l}\text { Combination of fixed } \\
\text { and variable charges } \\
\text { for certain cost } \\
\text { elements }\end{array}$ & $\begin{array}{l}\text { Open-book, cost plus } \\
\text { monthly charges helped } \\
\text { to reduce uncertainty } \\
\text { re: volumes and } \\
\text { resources; 'third party } \\
\text { guarantor' clause }\end{array}$ & $\begin{array}{l}\text { Incentive-based } \\
\text { mechanisms: } 50-50 \\
\text { split of savings } \\
\text { against annual budget }\end{array}$ \\
\hline $\begin{array}{l}\text { Penalties and } \\
\text { relief events } \\
\text { clauses }\end{array}$ & Safeguarding & $\begin{array}{l}\text { Escalating penalties } \\
\text { for failures; No } \\
\text { penalties for failures } \\
\text { attributable to } \\
\text { client; } 90 \text { days' } \\
\text { remedy period }\end{array}$ & $\begin{array}{l}\text { No penalties for } \\
\text { service failures; List } \\
\text { of client-caused } \\
\text { service failures; } \\
\text { failure analysis and } \\
\text { corrective action }\end{array}$ & $\begin{array}{l}\text { Escalating penalties; } \\
\text { No penalties for } \\
\text { failures/omission } \\
\text { attributable to client; } \\
60 \text {-day remedy period }\end{array}$ & $\begin{array}{l}\text { Penalty as fixed } \\
\text { amount per service } \\
\text { failure ( } £ 2,000) \text {; } \\
\text { Request for provider } \\
\text { rectification plans }\end{array}$ \\
\hline $\begin{array}{l}\text { Termination } \\
\text { clauses }\end{array}$ & Safeguarding & $\begin{array}{l}\text { Termination clause } \\
\text { for breach, changing } \\
\text { provider ownership } \\
\text { and bankruptcy; } \\
\text { short-term vehicle } \\
\text { leases defined }\end{array}$ & $\begin{array}{l}\text { Early termination } \\
\text { clause included to } \\
\text { hedge risks connected } \\
\text { to warehouse re- } \\
\text { location project, } \\
\text { although it was not } \\
\text { invoked; termination } \\
\text { rights for breach } \\
\text { established }\end{array}$ & $\begin{array}{l}\text { Early termination } \\
\text { clause \& termination } \\
\text { for breach; one-year } \\
\text { break in DC \& } \\
\text { equipment leases; } \\
\text { 'exclusive contractor' } \\
\text { clause }\end{array}$ & $\begin{array}{l}\text { Termination clause } \\
\text { for material breach } \\
\text { established (but not } \\
\text { used). Provisions for } \\
\text { changing provider } \\
\text { ownership and } \\
\text { bankruptcy }\end{array}$ \\
\hline $\begin{array}{l}\text { Performance } \\
\text { review and } \\
\text { communication } \\
\text { clauses }\end{array}$ & Coordination & $\begin{array}{l}\text { Monthly \& } \\
\text { quarterly meetings } \\
\text { and performance } \\
\text { reviews covering } \\
\text { service levels and } \\
\text { financial } \\
\text { performance }\end{array}$ & $\begin{array}{l}\text { Quarterly \& annual } \\
\text { meetings and review } \\
\text { of service level } \\
\text { performance and } \\
\text { costs; }\end{array}$ & $\begin{array}{l}\text { Monthly \& quarterly } \\
\text { meetings and review of } \\
\text { service level } \\
\text { performance; monthly } \\
\text { meetings helped to } \\
\text { identify deviations from } \\
\text { forecast sales and } \\
\text { logistics volumes }\end{array}$ & $\begin{array}{l}\text { Quarterly } \\
\text { performance review; } \\
\text { 'cooperation and } \\
\text { relationship } \\
\text { management' clause } \\
\text { also established } \\
\text { weekly operational } \\
\text { meetings to share } \\
\text { information }\end{array}$ \\
\hline $\begin{array}{l}\text { Renegotiation } \\
\text { clauses }\end{array}$ & Adaptation & $\begin{array}{l}\text { Annual review of } \\
\text { service budget and } \\
\text { costs; provisions of } \\
\text { price adjustments } \\
\text { were not used }\end{array}$ & $\begin{array}{l}\text { Annual renegotiation } \\
\text { of service costs and } \\
\text { provider prices; } \\
\text { provision for } \\
\text { changing cost and } \\
\text { provider charges re: } \\
\text { warehouse relocation } \\
\text { (not invoked) }\end{array}$ & $\begin{array}{l}\text { Annual budget } \\
\text { renegotiation and } \\
\text { provider payment } \\
\text { level/prices were used } \\
\text { to adjust solution }\end{array}$ & $\begin{array}{l}\text { Annual review } \\
\text { (service report) and } \\
\text { allowance for } \\
\text { renegotiation of the } \\
\text { cost model, budget } \\
\text { and prices; this was } \\
\text { used to renegotiate the } \\
\text { cost model and budget }\end{array}$ \\
\hline $\begin{array}{l}\text { Service } \\
\text { variations and } \\
\text { adjustment } \\
\text { clauses }\end{array}$ & Adaptation & $\begin{array}{l}\text { Provisions for } \\
\text { variations in } \\
\text { resource levels and } \\
\text { review of service } \\
\text { costs; these were } \\
\text { not invoked, though }\end{array}$ & $\begin{array}{l}\text { Allowance for } \\
\text { adapting resource } \\
\text { level changes (+- } \\
10 \% \text { ) and provider } \\
\text { payment level, } \\
\text { although this clause } \\
\text { was not used }\end{array}$ & $\begin{array}{l}\text { Provisions for } \\
\text { variations to service } \\
\text { resource and activity } \\
\text { levels }(+-10 \%) \text { were } \\
\text { invoked to reduce } \\
\text { resource levels and } \\
\text { costs }\end{array}$ & $\begin{array}{l}\text { 'Budget, changes to } \\
\text { charges and service' } \\
\text { clause was invoked to } \\
\text { adapt service } \\
\text { operations, costs and } \\
\text { payment model }\end{array}$ \\
\hline $\begin{array}{l}\text { Schedule(s) } \\
\text { amendments }\end{array}$ & Learning & $\begin{array}{l}\text { Tighter service } \\
\text { levels in renewed } \\
\text { contract; Contract } \\
\text { addendums for } \\
\text { service expansion } \\
\text { and warehouse } \\
\text { relocation }\end{array}$ & $\begin{array}{l}\text { Penalties connected to } \\
\text { delivery target } \\
\text { removed from } \\
\text { renewed contract; } \\
\text { reduced depot, trucks } \\
\& \text { product } \\
\text { loss/damage liabilities } \\
\text { in renewed contract }\end{array}$ & $\begin{array}{l}\text { Adjustment of payment } \\
\text { mechanism (fixed \% of } \\
\text { actual costs); reduced } \\
\text { resource levels and } \\
\text { costs by } 50 \%\end{array}$ & $\begin{array}{l}\text { Amendment of cost } \\
\text { model (cost per ton } \\
\text { budget) and payment } \\
\text { mechanism (from } \\
\text { savings sharing to } \\
\text { fixed \% of budget) } \\
\text { reflected in SOW }\end{array}$ \\
\hline
\end{tabular}


Table 4. Contract functions in relation to perceived uncertainty and relational experience

\begin{tabular}{|c|c|c|}
\hline Contract functions & Perceived uncertainty & Relational experience \\
\hline Codification & - & $\begin{array}{l}\text { Under extensive relational experience, } \\
\text { service specification schedules of the } \\
\text { contract are used to accurately codify the } \\
\text { service exchange (P1) }\end{array}$ \\
\hline \multirow[t]{2}{*}{ Safeguarding } & $\begin{array}{l}\text { Under extensive environmental } \\
\text { uncertainty, open book cost-plus } \\
\text { contracts are used to safeguard } \\
\text { contracting parties against financial } \\
\text { risks (P2) }\end{array}$ & $\begin{array}{l}\text { Customer's trust in provider competences } \\
\text { based on past service performance and } \\
\text { provider-specific knowledge may mediate } \\
\text { the safeguarding function of contracts by } \\
\text { removing clauses related to penalties, } \\
\text { liabilities, and so on. }\end{array}$ \\
\hline & $\begin{array}{l}\text { Under extensive behavioral } \\
\text { uncertainty, early termination } \\
\text { clauses hedge against potential } \\
\text { opportunism and related financial } \\
\text { losses (P3) }\end{array}$ & \\
\hline Coordination & $\begin{array}{l}\text { Under extensive perceived } \\
\text { uncertainty arising specifically from } \\
\text { service complexity, contractual } \\
\text { provisions for frequent performance } \\
\text { reviews are used to identify and } \\
\text { resolve operational issues (e.g. } \\
\text { service levels and costs) in a } \\
\text { coordinated way between the } \\
\text { customer and provider (P4) }\end{array}$ & - \\
\hline Adaptation & - & $\begin{array}{l}\text { Under limited relational experience, clauses } \\
\text { related to services variations/adjustment and } \\
\text { renegotiations are used to adapt the service } \\
\text { exchange e.g. in terms of resource levels, } \\
\text { costs and payment mechanisms (P5) }\end{array}$ \\
\hline Learning & $\begin{array}{l}\text { Under extensive perceived } \\
\text { uncertainty, exchange-specific } \\
\text { learning (e.g. related to customer } \\
\text { sales, volumes, resource levels, costs } \\
\text { and reward allocation) occurring } \\
\text { during contract execution is partly } \\
\text { reflected in the contract through } \\
\text { addendums or revised schedules }\end{array}$ & $\begin{array}{l}\text { Under extensive relational experience, } \\
\text { learning related to efficient collaboration } \\
\text { methods, service improvements and } \\
\text { provider competences is partly reflected into } \\
\text { the renewed contract through revised } \\
\text { specification schedules }\end{array}$ \\
\hline
\end{tabular}

